\title{
Investigation of the Potential Health Hazards of Petrol Station Attendants in Owerri Nigeria
}

\author{
${ }^{1}$ NWANJO, H U; ${ }^{2} *$ OJIAKO, O A \\ ${ }^{I}$ Dept of Med. Lab. Science, College of Medicine and Health Sciences, Imo State University, Owerri, \\ Nigeria. \\ ${ }^{2}$ Dept of Biochemistry, Federal Univ. of Technology, Owerri, Nigeria
}

\begin{abstract}
Possible biochemical changes in hepatic and renal functions due to exposure of petrol vapour were assessed in twenty (20) petrol station attendants in Owerri, Imo State, Nigeria. A corresponding twenty healthy subjects who were not exposed to petrol or its vapour were used as controls. The results showed a significant increase in the $(\mathrm{p}<0.05)$ activities of alkaline phosphatase, alanine and aspartate aminotransferases for those exposed to petrol vapour from 6-10 years while the plasma bilirubin concentrations showed no significant change $(p<0.05)$. Concentrations of serum urea, creatinine and urinary protein for those exposed to petrol vapour from 6-10 years were also significantly higher $(\mathrm{p}<0.05)$ when compared with the control. The results therefore indicate that exposure to petrol vapour increases the activities of some serum diagnostic liver enzymes and may also affect renal function indices. These effects, as seen from the study, are directly related to the duration of exposure and should be of interest to economic and environmental policy makers in Nigeria. @JASEM
\end{abstract}

Several hydrocarbons are potent inducers of cytochrome P450 that could lead to biological and health consequences. A high level of benzene in the breathing zone of fuel service station during refueling of automobiles has been reported (Tatrai et al, 1981). Benzene and related hydrocarbons are metabolized through an intermediate epoxide, which is highly reactive and possibly binds to hepatic microsomal proteins and nucleic acids leading to cytotoxic effects (Zahlsen et al, 1993). Petroleum hydrocarbons and other related carbon-containing compounds are converted into free radicals or activated metabolites during their oxidation in the cells (Zhu et al, 1996), especially mammalian liver and kidney cells. It is these activated metabolites that react with some cellular components such as membrane lipids to produce lipid peroxidation products (Onwurah, 1999) which may lead to membrane change. They may also react with enzymes and cause inactivation through protein oxidation (Stadtman, 1990) and/ or DNA strand breaks (Birnbiom et al, 1985). They are able to cause these latter effects because their metabolites can bind to proteins and nucleic acids. Exposure to petroleum and its products therefore constitute health hazards. Some of such hazards include nervous system damage, blood disorders (including anaemia, leukaemia), renal damage, hepatic dysfunction and intoxication leading to serious psychotic problems, anaesthetic effects, dermatitis etc. (Aryanpur, 1979). These observations were made mainly in experimental animals and often times these animals do not show any apparent symptoms of intoxication. Similarly, significant changes in clinical parameters of systemic impairment were hardly observed (Khan, et al 2002) even when the animals were repeatedly exposed, or administered orally by gavage, low dosages (0.5-2.5 $\mathrm{ml} / \mathrm{kg}$ ) of petrol. Systemic biochemical assessment, has however, shown that exposure to petrol caused marked changes in the activities of several enzymes in liver, kidney and lung tissues (Khann et al, 2002).

This study was undertaken to investigate the effects of exposure to petrol fumes on apparently healthy but consistent human passive inhalers of the fumes using volunteer petrol station attendants in Owerri Metropolis in Imo State of Nigeria. Such studies have not been carried out on ordinary Nigerian citizens and so the results obtained may aid in establishing some biological and health consequences of petrol vapour on petrol attendants from the Nigerian perspective. Such findings, it is also hoped, may find applications in fuel station design in Nigeria and even influence national policies in the downstream arm of petrol business in Nigeria.

\section{MATERIAL AND METHODS}

A total of forty (40) human volunteers were used for the study. Twenty (20) volunteers between the age of sixteen and thirty-eight years were drawn from petrol attendants in Owerri Metropolis. All the subjects have been directly exposed to petrol vapours in the course of their duties. Another twenty apparently healthy subjects who were not engaged in activities that predisposed them to serious contact with petrol vapour were recruited as controls for the study. After explaining the purpose and procedure of the research to all the subjects, their informed consent was obtained according to WHO standards (TDR, 2001; TDR, 2002).

Collection and Preparation of Samples: Mid stream early morning urine was collected in sterilized stericon universal containers by the volunteers each day until the end of study. Blood samples were collected from the volunteers by venipuncture using a 
sterile needle attached to syringe for each volunteer. Each specimen was put in a labeled sample bottle before transferring it into a centrifuge tube where it stood for 30 minutes to clot. The clotted blood samples were then centrifuged at $2500 \mathrm{~g}$ for 5 minutes using a Wisperfuge (model 684) centrifuge to obtain the serum samples used for bilirubin, urea, and creatinine determinations and also for enzyme assays.

\section{Determination of Biochemical Parameters:}

Urinalysis was performed using the Meditest Combi 9 strips. Total bilirubin and conjugated bilirubin were determined as described by Malloy and Evelyn (1937). The activities of plasma liver aminotransferases were determined by the method of Reitman and Frankel (1951). Alkaline phosphatase activity was assayed by the method of Bassey et al, (1947). Creatinine level in the plasma was determined using the Jaffe's method reported by Cheesbrough (1999). Urea was measured by the colorimetric method (Cheesbrough, 1999). Data collected were summarized as mean $\pm \mathrm{SD}$ and statistically analysed using Duncan's Multiple Range Test and a difference at $\mathrm{P} \leq 0.05$ was considered significant.

\section{RESULTS AND DISCUSSION}

Table 1 shows that the control group and the group exposed to fuel vapour from $1-5$ years did not show proteinuria. Instead, proteinuria appeared in the subjects exposed to petrol vapour for 6 years and above. There was a significant $(\mathrm{p}<0.05)$ increase in the mean concentrations of urea and creatinine for the group exposed to fuel vapour for $6-10$ years relative to the control group while no significant increase was observed for the group exposed for a maximum of five (5) years to the vapour. The results of the mean values of plasma total, conjugated and unconjugated bilirubin concentrations are presented in Table 2 . There were no significance differences $(\mathrm{P} \leq 0.05)$ in the mean values of total, conjugated and unconjugated bilirubin concentrations in the test groups relative to the control. Also shown in Table 2 is the result of the activities of the assayed liver enzymes. Statistical analyses of the results revealed that there were no significant differences $(P \leq 0.05)$ in the mean activities of AST, ALT and ALP of the group exposed to fuel vapour for 1-5 years relative to the control group but the mean activities of these parameters were significantly $(p<0.05)$ different when the control values are compared with the values obtained for those exposed to fuel vapours from 6-10 years.

Table 1: Biochemical changes in plasma creatinine, urea and urine protein of subjects exposed to petrol vapour and control.

\begin{tabular}{llcl}
\hline Parameters & Control & $1-5$ yrs exposure & $\begin{array}{l}6-10 \mathrm{yrs} \\
\text { exposure }\end{array}$ \\
Creatinine $(\mathrm{mg} / \mathrm{dl})$ & $0.98 \pm 0.21$ & $0.99 \pm 0.24$ & $1.6 \pm 0.36^{* *}$ \\
Urea $(\mathrm{mg} / \mathrm{dl})$ & $34.6 \pm 5.04$ & $37.6 \pm 4.98$ & $50.4 \pm 1.90^{* *}$ \\
Protein & Nil & Nil & trace** \\
\hline
\end{tabular}

*Significantly different from the control $(p<0.05) ; * * \quad$ Significantly different from control and 1-5yr exposure $(p<0.05)$

Enzymes are useful markers used in assessing specific functions and cell damage. Estimation of bilirubin levels and serum enzyme activities are of particular value in detecting hepatocellular dysfunction. An increase in these parameters may indicate liver disease, which may be due to hepatocellular damage, or due to toxins in drugs or herbs (Cheesbrough, 1999). In this investigation with petrol attendants exposed to petrol vapour in Owerri, the increases in the activities of serum aspartate and alanine aminotransferases and alkaline phosphatase for those exposed from $6-10$ years were significantly high when compared to the control. These finding are in agreement with the earlier report by Duricic and Duricic (1991) who also reported degenerative changes in renal and hepatic functions after exposing rats to light and heavy petrol. Increase in lipid peroxidation and protein oxidation in tissue membrane has been reported in several cases of toxicity induced by hydrocarbons, transition metals and xenobiotics, fenton reagent and even crude oil (Anozie and Onwurah, 2001). It has also been observed (Shibata et al, 1992) that consumption of petroleum hydrocarbon-contaminated diets could cause liver enlargement, growth depression and histological changes. The observed increase in the levels of liver diagnostic parameters in this study might be possibly due to toxic effects on the membranes of liver cells where petroleum hydrocarbons or carbon-containing compounds may have been converted into free radicals or activated metabolites during their oxidation. The apparent null effect of the vapour on bilirubin levels may be seen as a mere mask of the insidious damage of fuel vapour on body organs. This is because in some liver diseases, serum levels of enzymes will be elevated 
even before clinical symptoms of disease like levels are not expected to be raised. jaundice appear. Under such conditions bilirubin

Table 2: Biochemical changes in plasma levels of liver diagnostic parameters

\begin{tabular}{llcl}
\hline Parameters & Control & $1-5$ yrs exposure & 6-10yrs exposure \\
Total bilirubin $(\mathrm{mg} / \mathrm{dl})$ & $0.63 \pm 0.79$ & $0.68 \pm 0.14$ & $0.69 \pm 0.19$ \\
Conjugated bilirubin $(\mathrm{mg} / \mathrm{dl})$ & $0.29 \pm 0.54$ & $0.30 \pm 0.12$ & $0.34 \pm 0.13$ \\
Unconjugated bilirubin $(\mathrm{mg} / \mathrm{dl})$ & $0.34 \pm 0.38$ & $0.38 \pm 0.24$ & $0.35 \pm 0.12$ \\
Aspartate transaminase $(\mathrm{iu} / \mathrm{L})$ & $32.26 \pm 2.68$ & $34.0 \pm 4.21$ & $56.82 \pm 3.64^{* *}$ \\
Alanine transaminase $(\mathrm{iu} / \mathrm{L})$ & $30.8 \pm 2.9$ & $31.42 \pm 3.04$ & $48.2 \pm 3.35^{* *}$ \\
Alkaline phosphatase $(\mathrm{iu} / \mathrm{L})$ & $86.01 \pm 4.61$ & $87.92 \pm 5.20$ & $110.2 \pm 8.2^{* *}$ \\
\hline
\end{tabular}

* Significantly different from control $(p<0.05) ; * *$ significantly different from control and 1-5yr exposure $(p<0.05)$

This may also explain the observation in rats repeatedly exposed low dosages $(0.5-2.5 \mathrm{ml} / \mathrm{kg})$ of an Alberta crude oil (ACO) which showed no significant changes in clinical parameters of systemic impairment (Khan et al, 2002). The presence of trace protein in urine as well as the significantly increased levels of mean concentrations of creatinine and urea for attendants exposed to fuel vapour for up to 6 years indicate renal pathology and confirm the observation of Bartimaeus and Jacobs (2003) who showed that considerable exposure to petrol or its product over a long period of time could cause nephrotoxicity in motor mechanics occupationally exposed to them. An earlier report (Vyskocil et al, 1991) showed that besides being carcinogenic or mutagenic, petroleum products can be nephrotoxic eventuating in the urinary excretion of proteins and enzymes such as lactate dehydrogenase and $\mathrm{N}$-acetyl $-\beta-$ glucosaminidase. The finding in this study however, does not completely agree with the report of Olusi (1981) that a latency period of 10-25 years (depending on frequency, time, mode and concentration of exposure) exists before onset of effects. Our findings show that volunteers that have been exposed to the vapour for up to six years show clear signs of hepatorenal toxicity. Some of the factors that could exacerbate the deleterious effects of fuel vapour may therefore be at work in the environment of the Owerri metropolis.

In conclusion, our findings show that whole body exposure of Nigerian petrol attendants to petrol vapour could have long term effects on them since such exposure could cause hepatotoxicity and nephrotoxicity. There is therefore a need to modify the mode of operation of the petroleum business so as to safeguard the health of those continually exposed to the fumes.

\section{REFERENCES}

Alexander, S. K., and Schwartz, J. R. (2001). Short term effect of South Lousiana and Kuwaiti crude oils on glucose metabolism by marine bacterial population. Applied Environmental Microbial. 40: 341-345.

Aryanpur, I. (1979). Health hazards encountered in the petroleum industry. $10^{\text {th }}$ World Petroleum Congress Journal. Bucharest. 5: 235-242.

Bartimaeus, C. S. and Jacobs, M. J. (2003). The effect of exposure to petroleum products on some renal function parameters of motor mechanics in Port Harcourt Metropolis of Nigeria. Global Journal of Pure and Applied Sciences. 9(1): 59-63.

Bassey, O.A., Lowry, O.H. and Brock, M.J. (1947). Measurement of plasma alkaline phosphatase activity. Journal Biological Chemistry, 164: 321-322

Birnboim, H. C. and Kanabus-Kamiska, M. (1985). The production of DNA strand breaks in human leucocytes by superoxide anion may involve a metabolic process. Proceedings of National Academy of Science. 82:6820-6824.

Cheesbrough, M. (1999). District laboratory practice in tropical countries. $2^{\text {nd }}$ Edition, part 1, Cambridge University Press. Pp 207-212, 358360.

Duricic, J. and Duricic, G. (1991). Morphologic changes in the lungs, kidney and liver parenchyma in pregnant female rats treated with petroleum. Medical Archeology. 45: 23-25.

Khan, A. A.; Coppock, R. W.; Schuler, M. M. and Geleta, L. (2002) Biochemical changes as early 
stage systemic biomarkers of petroleum hydrocarbon exposure in rats. Toxicolology Letters ; 134(1-3):195-200

Malloy, H.T. and Evelyn, K.A. (1937) The Determination of Bilirubin with the Photoelectric Colorimeter. Journal of Biological Chemistry 119:481.

Onwurah, I. N. E. (1999). Lipid peroxidation and protein oxidation in Azotobacter vinelandii exposed to mercury, silver, crude oil and fenton reagent. Journal of toxic substances 18(4):167176.

Reitman, S.N. and Frankel, S. (1951). A colorimetric method for the determination of serum glutamic oxaloacetic, and glutamic pyruvic transaminases. American Journal of Clinical Pathology 28: 5663.

Shibata, K., Ashida, H. and Kanadawa, K. (1992). Effects of prolonged exposure to dietary DDT and $\mathrm{PCB}$ on rat liver morphology. Arc. Environ. Contam. Toxicol. 10: 171-183.

Stadtman, E. R (1990). Metal ion-catalyzed oxidation of proteins: biochemical mechanism and biochemical consequences. Free Rad. Biol. Med. 9: 315-325.

Tatrai, E., Ungavry, G., Cseh, I. R., Manyoi, S., Szeberenyi, S., Molnar, J. and Morvai, W. (1981). The effect of long-term whole body exposure to orthoxylene on liver. In: Industrial And Environmental Xenobiotics. I. Girkt and G. L. Plaa (eds), Springer-Verlag, Berlin. Pp 161168.

TDR (2002), Workbook for Investigators, UNDP/World Bank/WHO Special Programme for Research and Training in Tropical Diseases, (TDR/PRD/GCP/02.1b)

Vyskocit, A., Popler, A. and Skutilova, L. (1991). Urinary excretion of proteins and enzymes in workers exposed to hydrocarbons. International Archeology of Occupational and Environmental Health. 63: 359-362.

Zahlsen, K., Nielson, A. M., Eide, I. and Nielson, O. G. (1993). Inhalation kinetics of $\mathrm{C}_{8}-\mathrm{C}_{10}$, I alkenes and isoalkanes in rats after repeated exposure. Pharmacol. Toxicol. 73:163-168. 